\title{
Physiological and biochemical responses of hexaploid wheat cultivars to drought stress
}

\author{
Sunbal Khalil Chaudhari*, Muhammad Arshad and Noshin Ilyas \\ Department of Botany, PMAS Arid Agriculture University Rawalpindi-Pakistan \\ *Corresponding author's email: khalilsunbal@yahoo.com \\ Citation \\ Sunbal Khalil Chaudhari, Muhammad Arshad and Noshin Ilyas. Physiological and biochemical responses of \\ hexaploid wheat cultivars to drought stress. Pure and Applied Biology. Vol. 6, Issue 1, pp60-71. \\ http://dx.doi.org/10.19045/bspab.2016.50167
}

Received: 17/10/2016

Revised: 08/12/2016

Accepted: $14 / 12 / 2016$

Online First: 21/12/2016

\section{Abstract}

Wheat is the most important cereal crop; it is staple diet for more than one third of the world population. Wheat production is influenced by several harsh environmental stresses that adversely affect its growth, metabolism and yield. Among them, Drought stress is the main factor limiting the productivity of wheat crop worldwide. Plants experience drought stress either when the water supply to roots becomes difficult or when the transpiration rate becomes very high. These two conditions often coincide under arid and semi-arid climates. Eighty percent area of Pakistan comes under arid and semi-arid region, so wheat productivity is adversely reduced in these areas due to lack of rain fall. Wheat yield under drought stress can be improved by several methods like conventional breeding, genetic transformation and marker assisted selection. For applying any of these methods, a close scans of morphological and physio-biochemical parameters are necessary. In the present study with 92 genotypes, a decrease of $35.57 \%$ for relative water content and $23.08 \%$ was observed for chlorophyll content in the stressed conditions. And an increase in metabolite level such as sugar (28.86\%), SOD (4.53\%) and canopy temperature $(20.38 \%)$ was observed in moisture stress. Various genotypes have been identified which can be used further in plant breeding systems.

Keywords: Wheat; Drought; Genotypes; Physio-biochemical; Metabolites

\section{Introduction}

Meteorological drought (Discontinuity in precipitation) joined with higher evapotranspiration leads to agricultural drought [1]. Drought has been a major focus of research for several decades as due to climate change the number of drought periods will increase in the future [2]. With global warming, drought will occur more frequently and will be expected to affect crop production more severely [3]. Drought effects plants at cellular, physiological, metabolic and molecular levels and have serious impact on various developmental processes, such as seedling emergence and growth, root and shoot development and later leaf development [4-6]. Drought response studies are challenged by the complexity of the trait caused by the environmental interactions. Drought tolerance can be estimated by the mode, timing, and severity of the dehydration stress and its occurrence with other abiotic and biotic stress factors $[7,8]$. To counter 
adverse effects of different environmental stresses, plant have evolved special mechanisms and undergone a serial of physiological changes, but the "cross-talk of stresses" and "cross-tolerance to stresses" have not been extensively explored [9].

Crop genotypes having potential tolerance for environmental stresses is a common approach for improvement of crop productivity [10]. Drought tolerance is now considered by both plant breeders and biotechnologists to be a valid breeding target. Therefore some drought stress indices or selection criteria which provide a measure of drought based on yield loss under drought conditions in comparison to normal conditions have been used for screening drought tolerant genotypes [11-13].

Wheat is the major staple food in Pakistan, so it is cultivated and merchandized on commercial scale. Pakistan is among ten major wheat-producing countries of the world in terms of area under wheat cultivation, total productivity and per acre yield, It is recorded that Wheat currently contributes 75 percent of Pakistan's daily caloric diet with per capita wheat consumption of around $124 \mathrm{~kg}$ per year, one of the highest in the world $[14,15]$. Majority of area in Pakistan falls into arid-semi-arid regions, depending upon the climatic conditions. About $88 \%$ of total geographic area (79.6 mha) is covered by arid lands. The crop production in these areas is mainly dependent on the short and unpredictable rainfall [16, 17]. That's why, among different issues, water scarcity pose a serious threat to wheat production when less or no precipitation occurs in the year especially during winter [18].

Keeping in view the importance of wheat crop in Pakistan and problem of low yield in drought conditions as compared to developed countries it becomes imperative to take an immediate action to develop such varieties which can perform well under drought stress. So this study is planned for molecular and physiological evaluation of wheat cultivars for drought tolerance.

\section{Materials and methods}

Diverse germplasm of bread wheat was used for the study of genetic diversity and for screening drought tolerant genotypes using agronomic, morphological, physiological and molecular traits. The germplasm used in the study was comprised of 92 candidate lines. NARC-09, NARC-2011, Chakwal-95, Inqalab 98 was cultivated as control checks. Pedigree for selected genotypes is represented in Table S1.

Field experiments were carried out in year 2013-2014 and 2014-2015 at National agricultural research centre (NARC), Islamabad, Pakistan. Seeds were obtained from Wheat wide crosses, NARC, and were sown under control conditions in the tunnel and fully irrigated conditions in field following Randomized complete block design. Rain out plot shelters were covered with green sheets and plastic sheets to block water coming through precipitation. Tunnel was lined with 3 feet high brick wall underground to stop water seepage from surrounding areas. The seeds were sown in 1 meter rows having 3 replications. Non-stress plots were irrigated until maturity at sowing time, tillering, booting and post anthesis stage [19]. Various physiological and biochemical attributes like chlorophyll content [20], Canopy temperature [21] Relative water content [22], Electrolyte leakage [23] Proline content [24], Soluble carbohydrate content [25] and Superoxide dismutase activity $[26,27]$ were recorded. 
Table 1. Pedigree of genotypes used in the study

\begin{tabular}{|c|c|c|}
\hline Sr. No & Nursery Name & Pedigree \\
\hline 1 & SAWSN -11 & HIDDAB \\
\hline 2 & & KLEIN CACIQUE \\
\hline 3 & & BERKAT \\
\hline 4 & & W.15.92/4/Pastor//HXL7573/2*BAU/3WBLL1 \\
\hline 6 & & QG4.37A/4/MILAN/KAUZ/PRINIA/3/BAV92/5/... \\
\hline 7 & & ONIX/4/MILAN/KAUZ/PRINIA/3/BAV92 \\
\hline 8 & & ACHTAR/4/MILAN/KAUZ/PRINIA/3/BAV92 \\
\hline 9 & & CNO79//PF70354/MUS/3/PASTOR/4/BAV92/5/FRET2/... \\
\hline 10 & & CNO79//PF70354/MUS/3/PASTOR/4/BAV92/5/FRET2/... \\
\hline 11 & & CNO79//PF70354/MUS/3/PASTOR/4/BAV92/5/FRET2/... \\
\hline 12 & & MILAN/KAUZ/PRINIA/3/BAV92/4/ATTILA/BAV92//... \\
\hline 13 & & GK ARON//AGSECO7846//2180/4/2*MILAN/KAUZ//... \\
\hline 14 & & SW89-5124*2/FASAN/3/ALTAR84/AE.SQ//2*OPATA \\
\hline 15 & & SOKOLL/ROLF07 \\
\hline 16 & & SOKOLL/FRTL/2*PIFED \\
\hline 17 & & BAV92/SERI \\
\hline 18 & & MILAN/KAUZ/PRINIA/3/BAV92/4/WBLL1*2/KUKUNA \\
\hline 19 & & BOW/VEE/5/ND/VG9144//KAL/BB/3/YACO/4/CHIL/6/... \\
\hline 20 & & BOW/VEE/5/ND/VG9144//KAL/BB/3/YACO/4/CHIL/6/. \\
\hline 21 & & HUANIL//2*WBLL1*2/KUKUNA \\
\hline 22 & & FRET2*2/4/SNI/TRAP\#1/3/KAUZ*2/TRAP/KAUZ/5/. \\
\hline 23 & & ONIX/ROLFO7 \\
\hline 24 & & BARCENAS S 2002/4/MILAN/KAUZ/PRINIA/3/BAV92 \\
\hline 25 & & CNO79//PF70354/MUS/3/PASTOR/4/BAV92/5/FRET2/... \\
\hline 26 & & GK ARON//AGSECO7846//2180/4/2*MILAN/KAUZ//... \\
\hline 27 & & SW89-5142*2/FASAN/3/ALTAR 84/AE.SQ//2*OPATA \\
\hline 28 & & CNDO/R143//ENTE/MEXI_2/3/AEGILOPS SQUARROSA \\
\hline 29 & & CNDO/R143//ENTE/MEXI_2/3/AEGILOPS SQUARROSA \\
\hline 30 & & D67.2/PARANA 66.270// AE.SQUAROSSA(320)/3/... \\
\hline 31 & & PASTOR*2/BAV92/5/FRET2/KUKUNA/FRET2 \\
\hline 32 & & GOUBARA-1/2*SOKOLL \\
\hline 33 & & PSN/BOW//MILAN/3/2*PARUS/PASTOR \\
\hline 34 & & FRET2*2/4/SNI/TRAP\#1/3/KAUZ*2/TRAP/KAUZ/5/. \\
\hline 35 & SAWSN $-12 * *$ & GK ARON//AGSECO7846//2180/4/2*MILAN/KAUZ//... \\
\hline 36 & & SKUAZ/BAV92//SOKOLL \\
\hline 37 & & SERI*3//RL6010/4*YR/3/PASTOR/4/BAV92/5/. \\
\hline
\end{tabular}




\begin{tabular}{|c|c|c|}
\hline 38 & & VORB/3/T. DICOCCON PI94625/AE.SQUARROSA (32. \\
\hline 39 & & vORB/3/T. DICOCCON PI94625/AE.SQUARROSA (32. \\
\hline 40 & & CPI8/GEDIZ/3/GOO//ALB/CRA/4/AE. SQUARROSA $(20 \ldots \ldots)$ \\
\hline 41 & $\begin{array}{l}\text { SYNTHATIC } \\
\text { D- GENOME } \\
\text { SELECTION } \\
\end{array}$ & $\begin{array}{l}\text { 68.111/RGB-U//WARD/3/FGO/4/RABI/5/AE.SQUARROSA } \\
\text { (882)/6/ATTILA/10/ }\end{array}$ \\
\hline 42 & & URES/JUN//KAUZ/3/ALTAR 84/AE. SQ//2*OPATA \\
\hline 43 & & CROC_1/AE.SQUARROSA (205)//KAUZ/3/ENEIDA/4/FINSI \\
\hline 44 & & $\begin{array}{l}\text { FILIN/IRENA/5/CNDO/R143//ENTE/MEXI-2/3/AEGILOPS } \\
\text { SQUARROSA (TAUS)/4/WEAVER/6/... }\end{array}$ \\
\hline 45 & & $\begin{array}{l}\text { CNDO/R143//ENTE/MEXI_2/3/AEGILOPS SQUARROSA } \\
\text { (TAUS)/4/OCI/5/ }\end{array}$ \\
\hline 46 & & $\begin{array}{l}\text { FILIN/IRENA/5/CNDO/R143//ENTE/MEXI_2/3/AEGILOPS } \\
\text { SQUARROSA (TAUS)/4/WEAVER/6/BERKUT }\end{array}$ \\
\hline 47 & & $\begin{array}{l}\text { FILIN/IRENA/5/CNDO/R143//ENTE/MEXI_2/3/AEGILOPS } \\
\text { SQUARROSA (TAUS)/4/WEAVER/6/BERKUT }\end{array}$ \\
\hline 48 & & CROC_1/AE.SQUARROSA (205)//KAUZ/3/2*PJN/BOW//OPATA \\
\hline 49 & 7HTWSN*** & SAUL/3/ACHTAR *3//KANZ/KS85-8-4/4/SAUL \\
\hline 50 & & KACHU\#1/3/C80.1/3*BATAVIA//2*WBLL1/4/KACHU \\
\hline 51 & & SAUL\#1/KACHU \\
\hline 52 & & SAUL\#1/KACHU \\
\hline 53 & & D67.2/PARANA 66.270// AE.SQUAROSSA(320)/3/... \\
\hline 54 & & VORB/3/T. DICOCCON PI94625/AE.SQUARROSA (372) \\
\hline 55 & & CNDO/R143//ENTE/MEXI-2/3/AEGILOPS SQUARROSA \\
\hline 56 & & D67.2/PARANA 66.270// AE.SQUAROSSA(320)/3/... \\
\hline 57 & & T. DICOCCON PI225332/ AE.SQUARROSA (895)// ... \\
\hline 58 & & D67.2/PARANA 66.270// AE.SQUAROSSA(320)/3/. \\
\hline 59 & 4CSiSA-SB*** & d67.2/PARANA 66.270// AE.SQUAROSSA(320)/3/Cunningham/4/. \\
\hline 60 & & MUU/4/BAV92//IRENA/KAUZ/3/HUITES/5/BAV92//IRENA/KAUZ/3/.. \\
\hline 61 & & PBW343*2/KHVAKI*2/3/ACHTAR*3//KANZ/KS85-8-5 \\
\hline 62 & & CHIR3/4/SIREN//ALTAR84/AE.SQUARROSA (205)/3/3*BUC/5/... \\
\hline 63 & & VORB/3/T. Dicoccon PI94625/ AE. SQUARROSA (372)//3*PASTOR \\
\hline 64 & & MURGA/KRONSTAD F2004 \\
\hline 65 & & CHIRYA. 3 \\
\hline 66 & & Kachu\#1/4/croc_1/ AE. SQUARROSA (205)// KAUZ/ 3/ \\
\hline 67 & & CNDO/R143//ENTE/MEXI_2/3/AEGILOPS SQUARROSA (TAUS)/4/... \\
\hline 68 & & VORB/4/D67.2//PARANA 66.270//AE. SQUARROSA (320)/3/... \\
\hline 69 & $\begin{array}{l}\text { HISTORICAL } \\
\text { SET* }\end{array}$ & OPATA/RAYON//KAUZ \\
\hline 70 & & WL-711/CROW'S \\
\hline 71 & & TD-1 \\
\hline
\end{tabular}




\begin{tabular}{|l|l|l|} 
& & $\begin{array}{l}\text { BLUEBIRD/GALLO/3/GABOTO/SIETE-CERROS- } \\
\text { 66//BLUEBIRD/CIANO-67 }\end{array}$ \\
\hline 72 & & CHAKWAL-97 \\
\hline 74 & & Oasis/Skauz//4*BC/3/2*Pastor \\
\hline 75 & & KVZ//BUHO//KALBB \\
\hline 76 & & MUNIA/SHTO//AMSEL \\
\hline 77 & & DWL-5023/SUNBIRD,MEX//SUNBIRD,MEX \\
\hline 78 & & ATTILA/3/HUI/CARC//CHEN/CHTO/4/ATTILA \\
\hline & & CHILERO/2*STAR/4/BOBWHITE//BUCKBUCK/PAVON- \\
\hline 79 & & F16/3/2*VERY-10 \\
\hline 80 & & KAUZ/PASTOR \\
\hline 81 & & INQALAB 91*2/TUKURU \\
\hline 82 & & MILAN/S87230//BABAX \\
\hline 83 & RF (NUWYT)* & SOKOLL/3/PASTOR//HXL7573/2*BAU \\
\hline 84 & & GA-2002/Chakwal-50 \\
\hline 85 & & PASTOR/MILAN//MILAN/kauz \\
\hline 86 & & PFAU/SERIIB//AMAD/3/WAXWING \\
\hline 87 & & TC870344/GUI/TEMPORALERAM87/AGR/3/2*WVLL1 \\
\hline 88 & & W15.92/4/PASTOR//HXL7573/2*BAU/3/WBLL1 \\
\hline 89 & & 9 B039 \\
\hline 90 & & RFVOBT022* \\
\hline 91 & RFVOBT022* \\
\hline 92 & Turaco/FCT 73* & Turaco/FCT 73* \\
\hline
\end{tabular}




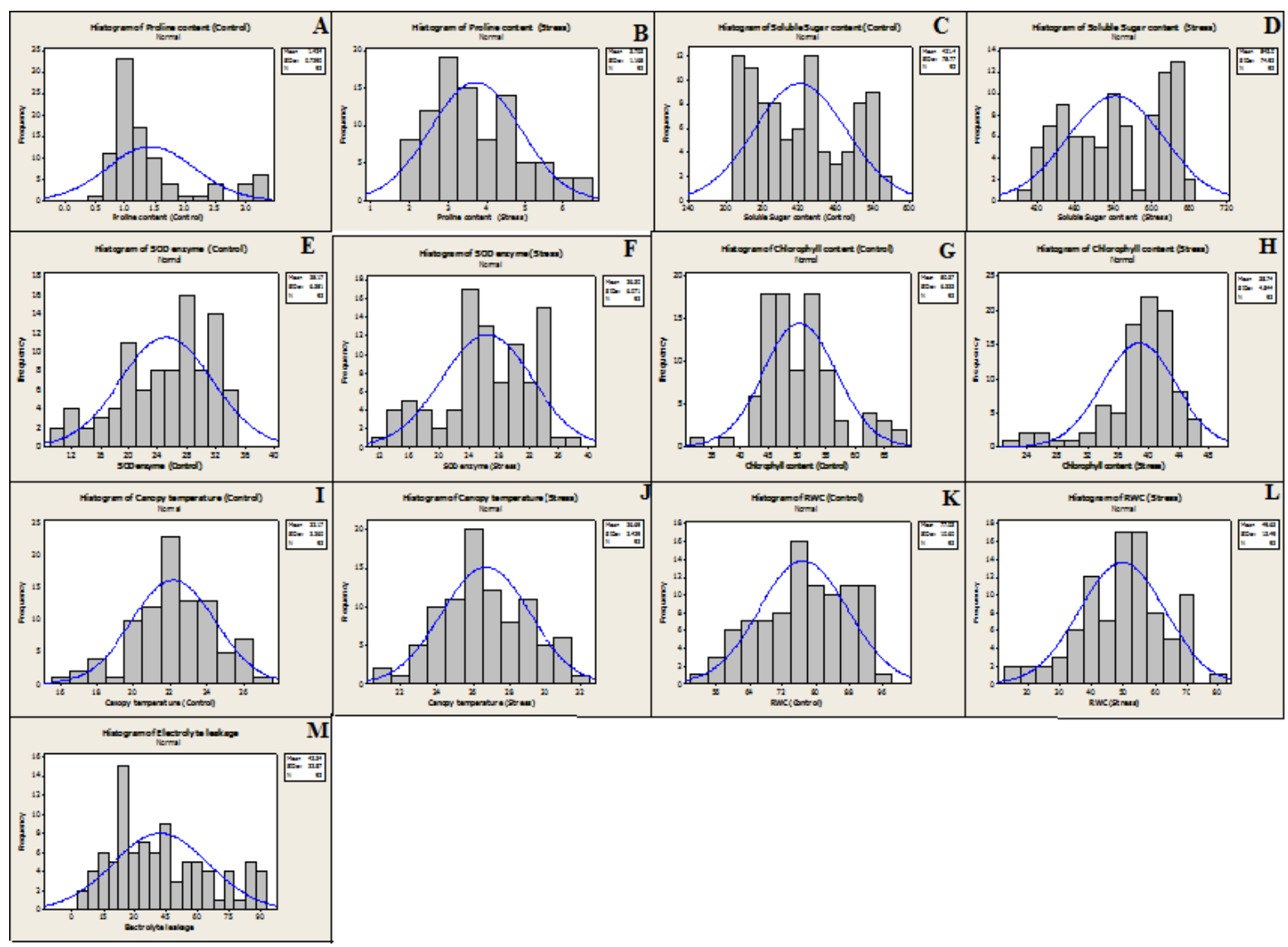

Figure 1. Frequency distribution of biochemical and physiological parameters. (A). Proline content (Control) (B). proline content (Stress) (C). Soluble carbohydrate content (Control) (D). Soluble carbohydrate content (Stress) (E). Super oxide dismutase enzyme (control) (F). Super oxide dismutase enzyme (Stress). (G). Chlorophyll content (Control). (H). Chlorophyll content (Stress) (I). Canopy temperature (Control). (J). Canopy temperature (Stress). (K). Relative water content (Control) (L). Relative water content (Stress) (M). Electrolyte leakage

\section{Results}

Drought stress tolerance is a very complicated phenomenon involving numerous metabolic adjustments. Analyses of metabolic pathways provide important supplementing evidence for better understanding of stress mechanisms [28]. Drought tolerance can be mediated by biochemical compounds such as amino acids like proline, organic acids and sugars by acting as compatible solutes to maintain cellular functions $[29,30]$.

Highly significant difference was observed for treatments, genotypes and their interactions for all the physiologicalbiochemical parameters at $\mathrm{p}<0.001$.
However, for some parameters, no significant difference was observed between the two years of observation and the interactions. All the results of analysis of variance are depicted in Table 1. Descriptive statistics for all the treatments is depicted in Table 2. Overall, the drought stress had an inhibitory effect on chlorophyll and relative water content, but the production of sugar, proline, SOD was increased. Canopy temperature and electrolyte leakage also increased in drought stress treatment. A decrease of $35.57 \%$ for relative water content and $23.08 \%$ was observed for chlorophyll content in the stressed conditions. Other metabolites increased in 
stressed conditions, such as sugar $(28.86 \%)$, SOD $(4.53 \%)$ and $20.38 \%$ increase for

Table 2. Analysis of variance for physiological and biochemical parameters

\begin{tabular}{|c|c|c|c|c|c|c|c|c|c|c|}
\hline \multirow[b]{2}{*}{ Source } & \multirow[b]{2}{*}{$\mathrm{DF}$} & \multicolumn{3}{|c|}{ Proline content } & \multicolumn{3}{|c|}{ Sugar content } & \multicolumn{3}{|c|}{$\begin{array}{l}\text { Superoxide dismutase } \\
\text { enzyme }\end{array}$} \\
\hline & & Adj MS & $\mathrm{F}$ & $\mathrm{P}$ & Adj MS & $\mathrm{F}$ & $\mathrm{P}$ & Adj MS & $\mathrm{F}$ & $\mathrm{P}$ \\
\hline Genotypes & 91 & 3.3369 & 370.68 & 0 & 21776 & 723.71 & 0 & 158.58 & 389.22 & 0 \\
\hline Year & 1 & 0.0342 & 3.8 & 0.044 & 101360 & 3368.57 & 0 & 103.84 & 254.86 & 0 \\
\hline Treatments & 1 & 446.0944 & 49554.42 & 0 & 1623690 & 53961.47 & 0 & 207.18 & 508.51 & 0 \\
\hline genotypes*year & 91 & 0.2927 & 32.51 & 0 & 518 & 17.2 & 0 & 0.54 & 1.33 & 0.086 \\
\hline genotypes*treatments & 91 & 0.005 & 0.56 & 0.997 & 39 & 1.31 & 0.101 & 1.67 & 4.09 & 0 \\
\hline year*treatments & 1 & 0.5441 & 60.44 & 0 & 11600 & 385.5 & 0 & 12.4 & 30.44 & 0 \\
\hline \multirow[t]{2}{*}{ Error } & 91 & 0.009 & & & 30 & & & 0.41 & & \\
\hline & & \multicolumn{3}{|c|}{ Chlorophyll content } & \multicolumn{3}{|c|}{ Canopy temperature } & \multicolumn{3}{|c|}{ Relative water content } \\
\hline Source & & Adj MS & $\mathrm{F}$ & $\mathrm{P}$ & Adj MS & $\mathrm{F}$ & $\mathrm{P}$ & Adj MS & $\mathrm{F}$ & $\mathrm{P}$ \\
\hline Genotypes & 91 & 115.69 & 262.11 & 0 & 21478 & 48.04 & 0 & 549.8 & 224.57 & 0 \\
\hline Year & 1 & 3.8 & 8.61 & 0.004 & 1400451 & 3132.22 & 0 & 198.4 & 81.05 & 0 \\
\hline Treatments & 1 & 12787.91 & 28971.33 & 0 & 516305 & 1154.76 & 0 & 65952.7 & 26938.95 & 0 \\
\hline genotypes*year & 91 & 9.27 & 21 & 0 & 0.454 & 1.02 & 0.47 & 2.7 & 1.08 & 0.352 \\
\hline genotypes*treatments & 91 & 0.15 & 0.33 & 1 & 544637 & 1218.12 & 0 & 20.4 & 8.33 & 0 \\
\hline year*treatments & 1 & 2.42 & 5.49 & 0.021 & 0.315 & 0.7 & 0.952 & 35.9 & 14.68 & 0 \\
\hline \multirow[t]{2}{*}{ Error } & 91 & 0.44 & & & 0.447 & & & 2.4 & & \\
\hline & & \multicolumn{3}{|c|}{ Electrolyte leakage } & & & & & & \\
\hline Source & & Adj MS & $\mathrm{F}$ & $\mathrm{P}$ & & & & & & \\
\hline Genotypes & 91 & 1008.2 & 609.4 & 0 & & & & & & \\
\hline Year & 1 & 44.28 & 26.77 & 0 & & & & & & \\
\hline Error & 91 & 1.65 & & & & & & & & \\
\hline
\end{tabular}

Table 3. Descriptive statistics for biochemical and physiological parameters

\begin{tabular}{|l|l|l|l|l|l|l|l|l|}
\hline Variable & Minimum & Maximum & Mean & SE Mean & Median & StDev & Variance & CoefVar \\
\hline Proline content & & & & & & & & \\
\hline Irrigated & 0.46 & 3.37 & 1.42 & 0.07 & 1.13 & 0.72 & 0.53 & 51.18 \\
\hline Stress & 1.84 & 6.74 & 3.7 & 0.12 & 3.49 & 1.16 & 1.35 & 31.45 \\
\hline Sugar content & & & & & & & & \\
\hline Irrigated & 311.11 & 557.3 & 421.39 & 7.9 & 418.01 & 75.77 & 5740.76 & 17.98 \\
\hline Stress & 408.33 & 658 & 543.01 & 7.81 & 544.31 & 74.92 & 5612.97 & 13.8 \\
\hline $\begin{array}{l}\text { Superoxide dismutase } \\
\text { enzyme }\end{array}$ & & & & & & & & \\
\hline Irrigated & & & & & & & \\
\hline Stress & 9.66 & 34.16 & 25.16 & 0.66 & 26.22 & 6.35 & 40.33 & 25.23 \\
\hline Chlorophyll & 12.16 & 37.83 & 26.3 & 0.63 & 26.41 & 6.07 & 36.86 & 23.08 \\
\hline Irrigated & & & & & & & & \\
\hline Stress & 33.4 & 68.1 & 50.37 & 0.66 & 49.26 & 6.33 & 40.1 & 12.57 \\
\hline Canopy temperature & 21.73 & 46.23 & 38.74 & 0.5 & 39.9 & 4.84 & 23.46 & 12.5 \\
\hline Irrigated & & & & & & & \\
\hline Stress & 15.67 & 27 & 22.17 & 0.23 & 22 & 2.26 & 5.1 & 10.19 \\
\hline Relative water content & 21 & 32.33 & 26.69 & 0.25 & 26 & 2.42 & 5.9 & 9.1 \\
\hline Irrigated & & & & & & & & \\
\hline Stress & 53.74 & 94.55 & 77.03 & 1.11 & 77.53 & 10.6 & 112.35 & 13.76 \\
\hline Electrolyte leakage & 14.88 & 81.66 & 49.63 & 1.41 & 50.53 & 13.49 & 182.09 & 27.19 \\
\hline & & & & & & & & 54.02 \\
\hline
\end{tabular}




\section{Soluble carbohydrate content}

Carbohydrate changes are of particular importance on account of their direct relationships with physiological processes such as ABA signaling, photosynthesis, translocation and respiration. [31]. As a result of drought stress, amylase activity increases, soluble sugar content increases by decomposing starch [32]. In the present experiment, changes in soluble carbohydrate content during water stress and recovery were examined in leaves of 92 varieties of bread wheat and there was significant difference $\mathrm{P}<0.01$ was observed among genotypes in irrigated and stress conditions. Interactions between genotypes and treatments have shown no significant difference in observations as depicted in anova results. The mean values for controlled treatment were ranged from 311.11 to $557.30 \mu \mathrm{g} / \mathrm{g}$. An increase in sugar content was observed when water stress was applied. The readings ranged from 408.33543.01 in both years. Maximum suger content value in stressed conditions was observed in AG-024 which was $658 \mu \mathrm{g} / \mathrm{g}$. These results were in accordance with [33]. who observed that the soluble carbohydrate concentration in well-watered wheat plants was lower than those of stressed plants.

\section{Proline content}

Proline (content) is closely related to stress tolerance especially under soil water deficits [34]. Many reports from crops and other plants have proved this relationship [35, 36]. There was significant difference $\mathrm{P}<0.005$ observed between genotypes for proline content in year 2013-2014 and 20142015. However interaction between genotypes and treatments did not show any significant difference. The mean value for irrigated and stress treatments were 1.42 and 3.7 respectively. Maximum value for proline content in irrigated conditions was 3.48 and in stress condition an increase upto 6.74 was noticed in both years. Minimum values for proline content was recorded in AG-091 which was 0.62 (control) and 1.7 (Stress). These results are in accordance with [37]. who stated that proline content increases under water stress

\section{Super oxide dismutase enzyme}

The major reactive oxygen species (ROS) scavenging mechanisms include superoxide dismutase (SOD), enzymes and metabolites from the ascorbate-glutathione cycle, and catalase (CAT). They are located throughout the different compartments of the plant cell. SOD is the front-line enzyme in ROS attack since it rapidly scavenges superoxide, one of the first ROS to be produced [38, 39]. Significant differences were observed for the values of SOD enzymes among genotypes, treatments and years. For both years the SOD values ranged from 9.50 to 12.16 in controlled conditions and from 33.34 to 37.83 in stressed conditions. Significant increase was observed for the genotypes with stress treatment. Minimum SOD values were observed for AG091(12.16 and 10.23) and maximum (34.55 and 35.58) for AG-028 in stressed conditions. These results were in contrast to [40]. Who observed that Superoxide dismutase (SOD) activity was very low and showed non-significant increase under water-stress in tolerant genotypes. However the results were consistent with the findings of [41]. who speculated that superoxide dismutase (SOD) activity increased with the decrease in osmotic potential in drought.

\section{Chlorophyll content}

To check for delayed senescence of leaves, particularly flag leaves, portable chlorophyll meters such as the Minolta SPAD are extensively used, due to their speed and ease of use $[42,43]$. In stressed vegetation, leaf chlorophyll shows decrease suggesting an overall drop in light absorption [44-46]. Chlorophyll content values were significant for all the genotypes. The interaction between genotypes and treatments did not 
show much significant differences. Chlorophyll content values ranged from 33.40 to 68.10 in irrigated and were decreased to 21.73-46.17 in stressed conditions. The results proved the findings of [3]. who concluded that a reduction of the chlorophyll content under drought stress conditions occurs which may be due to a reduced leaf growth under drought stress conditions resulting in a reduced cell expansion leading to a relatively lower chlorophyll density in the leaves.

\section{Canopy temperature}

Canopy temperature can provide information on transpiration as the main contributor to reduced leaf temperature [47,
48] and it is taken as a relative measure of water flow associated with water extraction from the soil under water deficit [49]. Mean canopy temperature in irrigated conditions for both years was observed around 22.2 and in stressed treatment it was increased to 26.69 mean values. The reults were highly different for genotypes, treatments and years but no significant difference for the canopy temperature values was noticed for interactions of genotypes and treatments awith the years. Highest difference in canopy temperature was observed in AG034 (31.67 in irrigated and 21 in stressed conditions) and minimum in AG-024 (16 in irrigated and 21 in stressed conditions).

Table 4. Drought tolerant lines based upon physio-biochemical attributes

\begin{tabular}{|c|c|c|c|c|}
\hline Genotypes & Proline $(\boldsymbol{\mu m o l} / \mathbf{g})$ & Sugar $(\boldsymbol{\mu g} / \mathbf{g})$ & SOD & CT \\
\hline AG-010 & 6.12 & 651.29 & 33.31 & 23 \\
\hline AG-012 & 5.95 & 643.64 & 35.27 & 23.67 \\
\hline AG-017 & 6.28 & 655.56 & 29.54 & 26.67 \\
\hline AG-024 & 6.66 & 658 & 23.89 & 29 \\
\hline AG-051 & 6.03 & 644.45 & 35.98 & 25.33 \\
\hline
\end{tabular}

\section{Relative water content and electrolyte leakage}

The results were highly significant for genotypes and treatments among the years for relative water content. However no significant difference was observed for interaction between genotypes and years. In year 2013-2015 relative water content ranged from 53.74-94.55 in irrigated and 14.88 to 81.66 in stressed conditions. Results obtained were highly significant among genotypes and treatments for both years. Under stressed conditions cell membranes are subject to changes often associated with the increase in the cell permeability [50]. In case of electrolyte leakage as a measure of cell membrane stability (CMS) there was normal distribution of trait. The genotype AG029 had highest electrolyte leakage of $91.2 \%$. The electrolyte leakage progressively amplified with increasing drought severity.
These results are in agreement with those of $[33,51,52]$.

Conclusion

The present study was carried out to demonstrate that genetic variation can cause drought resistance in plants growing in dry and semi-dry regions of Pakistan and similar countries in the world. Our results revealed that different wheat cultivars can cope with drought stress by employing strategies such as the production of compatible solutes (reducing sugars, proline) and antioxidant enzymes. The cultivars given in Table 3 might be considered as a suitable candidate for cultivation in semi-arid regions of this country.

\section{Authors' contributions}

Research planning, undertaking and analysis: SK Chaudhari, Supervision of the whole research plan and write up: M Arshad and N Ilyas. 


\section{References}

1. Mishra V \& Cherkauer KA (2010). Retrospective droughts in the crop growing season: implications to corn and soybean yield in the midwestern United States. Agric Meteorol 150: 1030-1045

2.Ashraf M (2010). Inducing drought tolerance in plants: recent advances. Biotechnol Adv 28:169-83.

3.Wehner GG, Balko CC, Enders MM, Humbeck KK \& Ordon FF (2015). Identification of genomic regions involved in tolerance to drought stress and drought stress induced leaf senescence in juvenile barley. BMC Plant biol 15(125): 1-15.

4.Prasad PVV, Pisipati SR, Momcilovic I \& Ristic Z (2011). Independent and Combined Effects of High Temperature and Drought Stress During Grain Filling on Plant Yield and Chloroplast EF-Tu Expression in Spring Wheat. J Agron Crop Sci 197: 430-41.

5.Finkelstein RR, Gampal SSL \& Rock CD (2002). Abscisic acid signaling in seeds and seedlings. Plant Cell 14: S15-S45.

6.Xiong L, Wang RG, Mao G \& JKoczan JM (2006). Identification of drought tolerance determinants by genetic analysis of root response to drought stress and abscisic acid. Plant Physiol 142(3): 1065-1074.

7. Yaish MW, Colasanti J \& Rothstein SJ (2011). The role of epigenetic processes in controlling flowering time in plants exposed to stress. J Exp Bot 62(11): 3727-3735.

8.Reynolds MP (2006). Drought adaptation in wheat," in Drought Tolerance in Cereals, J. M. Ribaut, Ed., chapter 11, pp. 402436, Haworth's Food Products Press, New York, NY, USA.

9.Budak H, Kantar M \& Kurtoglu KY (2013). Drought Tolerance in Modern and Wild Wheat. Sci World J 2013: 1-16.

10. Khan J, Khan S, Khetran MA, Amanullah, Sadiq N, Islam M, Hanan A \& Aziz A (2013). Tijaban-10 a drought tolerant and high yielding wheat variety for rainfed/sailaba areas of Balochistan. Pak $J$ Bot 45(4): 1357-1362.

11. Talebi R, Fayaz F \& Naji AM (2009). Effective selection criteria for assessing drought stress tolerance in durum wheat (Triticum durum Desf.). Gen Appl Plant Physiol 35: 64-74.

12. Mohammadi R, Armion M, Kahrizi D \& Amri A (2010). Efficiency of screening techniques for evaluating durum wheat genotypes under mild drought conditions. Inter J Plant Prod 4 (1): 1124.

13. Nouri A, Etminan A, Teixeira da Silva JA \& Mohammadi R (2011). Assessment of yield, yield-related traits and drought tolerance of durum wheat genotypes (Triticum turjidum var. durum Desf.). Aust J Crop Sci 5 (1): 8-16.

14. PARC (2015). Wheat In Pakistan: A status paper. National Coordinator Wheat Plant Sciences Division Pakistan Agricultural Research Council Islamabad, Pakistan. P 1-9.

15. USDA (2015). Pakistan grain and feed annual.USDA foreighn agricultural service. 1-4.

16. Ahmad N, Rashid M \& Vaees AG (1996). Fertilizers and their Use in Pakistan. NFDC Pub. No. 4/96. Planning Commission NFDC, Islamabad, Pakistan.

17. Mujtaba SM \& Alam SM (2002). Drought phenomenon and crop growth http://www.Pakistaneconomist.com/ issue 2002/ issue13/iande4.htm.

18. Kazmi RH, Khan MQ \& Abbasi MK (2003). Effect of water stress on the performance of wheat grown under controlled conditions at Rawalakot, Azad Jammu and Kashmir. Sarhad J Agric 19: 61-67.

19. Bashir AL \& Bantel R (1994). Crop production. National book foundation. pp. 163.

20. Mullan D \& Mullan D (2012). Chapter 9; Chlorophyll content. In: Pask A.J.D, Pietragalla J, Mullan D.M., and 
Reynolds M.P. (Eds.). Physiological Breeding II: A field guide to Wheat phenotyping. Mexico, D.F. CIMMYT; pp: 41-43

21. Pietragalla J (2012). Canopy temperature In: Pask A, J. Pietragalla, D. Mullan, M. P. Reynolds, editors.Physiological breeding II: A field guide to wheat phenotyping. D. F., Mexico: CIMMYT; pp. 10-14.

22. Bars HD \& Weatherly PE (1962).“Are Examination of the Relative Turgidity Technique for Estimating Water Deficit in Leaves?" Aust. J Biol Sci 15: 413428.

23. Tripathy J, Zhang J, Robin S, Nguyen TT \& Nguyen H (2000). QTLs for cellmembrane stability mapped in rice (Oryza sativa L.) under drought stress. Theor. Appl Genet 100: 1197-1202

24. Bates LS, Waldran RP \& Teare ID (1973). Rapid determination of free proline for water stress studies. Plant Soil 39: 205208.

25. Dubois M, Gilles KA, Hamilton JK, Rebers PA \& Smith F (1956). Colorimetric method for determination of sugars and related substances. Anal Chem 28: 350-356

26. Beauchamp $\mathrm{CH} \&$ Fridovich I (1971).Superoxide dismutase: improved assays and an assay applicable to acrylamide gels. Anal Biochem 44:276287.

27. Gianopolitis CN \& Ries SK (1977). Superoxide dismutase: purification and quantitative relationship with watersoluble protein in seedling. Plant Physiol 59: 315-318.

28. Muscolo A, Junker A, Klukas C, Weigelt-Fischer K, Riewe D \& Altmann T (2015). Phenotypic and metabolic responses to drought and salinity of four contrasting lentil accessions. J Exp Bot 10(1093): 1-14.

29. Blum A (2015). Towards a conceptual ABA ideotype in plant breeding for water limited environments. Funct. Plant Biol 42(6) 502-513.
30. Naeem MK, Rauf S, Iqbal H, Shah MKN \& Mir A (2013). In-silico studies of C3metabolic pathway proteins of wheat (Triticum aestivum). Bio Med Res Int Article ID 294759

31. Kameli A \& Losel DM (2006). Carbohydrates and water status in wheat plants under water stress. New Phytol 125: 609-614.

32. Vaezi H (2005). Evaluation of molecular characters in wheat. M.Sc. Thesis, College of Agriculture Razi University, Kermanshah, Iran.

33. Zhang X, Ervin EH, Evanylo GK \& Haering KC (2009). Impact of Biosolids on Hormone Metabolism in DroughtStressed Tall Fescue. Crop Sci 49(5): 2009-1893

34. Hong-Bo S, Xiao-Yan C, Li-Ye C, XiNing Z, Gang W, Yong-Bing Y, ChangXing Z \& Zan-Min H (2006). Investigation on the relationship of proline with wheat anti-drought under soil water deficits. Coll Surf B 53: 113119.

35. Rampino P, Pataleo S, Gerardi C, Mita G \& Perrotta C (2006). Drought stress response in wheat: physiological and molecular analysis of resistant and sensitive genotypes. Plant Cell Environ 29: 2143-2152.

36. Yu X, Li B, Wang L, Chen X, Wang W, Gu Y, Wang Z \& Xiong F (2015). Effect of drought stress on the development of endosperm starch granules and the composition and physicochemical properties of starches from soft and hard wheat. $J$ Sci Food Agric doi 10.1002/jsfa.7439

37. Esfandiari E, Shakiba MR, Mahboob SA , Alyari H , Shahabivand S. (2006). The effect of water stress on the antioxidant content, protective enzyme activities, proline content and lipid peroxidation in wheat seedling. Pak $J$ Biol Sci 11(15): 1916-22.

38. Noctor G, Veljovic-Jovanovic S, Driscoll S, Novitskaya L \& Foyer C (2002). Drought and oxidative load in the leaves 
of C3 plants: A predominant role for photorespiration? Ann Bot 89: 841-850.

39. Cruz de Carvalho MH (2008). Drought stress and reactive oxygen species Production, scavenging and signaling. Plant Signal Behav 3(3): 156-165.

40. Devi R, Kaur N \& Gupta A (2012). Potential of antioxidant enzymes in depicting drought tolerance of wheat (Triticum aestivum L.). Indian $J$ Biochem Biophys 49:257-265.

41. Hassan NM, El-Bastawisy ZM, El-Sayed AK, Ebeed HT \& Nemat Alla MM (2015). Roles of dehydrin genes in wheat tolerance to drought stress. $J A d v$ Res 6(2): 179-188.

42. Rharrabti Y, Villegas D, García del Moral LF, Aparicio N, El Hani S \& Royo C (2001).Environmental and genetic determination of protein content and grain yield in durum wheat under Mediterranean conditions. Plant Breed 120: 381-388.

43. Monneveux P, Jing R \& Misra SC (2012). Phenotyping for drought adaptation in wheat using physiological traits. Front Physiol 3: 429.

44. Long SP, Zhu XG, Naidu SL \& Ort DR (2006). Can improvement in photosynthesis increase crop yields? Plant Cell Environ 29: 315-330.

45. Raines CA (2011). Increasing photosynthetic carbon assimilation in $\mathrm{C} 3$ plants to improve crop yield: current and future strategies. Plant Physiol 155: 3642.

46. Flexas J, Ribas-Carbó M, Bota J, Galmés J, Henkle M, Martínez-Cañellas S,
Medrano H, Flood PJ, Harbinson J \& Aarts MGM (2011). Natural genetic variation in plant photosynthesis. Trend. Plant Sci 16: 327-335.

47. Araus JL, Slafer MP, Reynolds MP \& Royo C (2002). Plant breeding and drought in C3 cereals: what should we breed for? Ann Bot 89: 925-940.

48. Royo C, Villegas D, Garc'ia del Moral LF, El Hani S, Aparicio N, Rharrabti Y $\&$ Araus JL (2002). Comparative performance of carbon isotope discrimination and canopy temperature depression as predictors of genotype differences in durum wheat yield in Spain. Aust. J Agr Res 53: 561-569.

49. Reynolds M, Dreccer F \& Trethowan R (2007). Drought-adaptive traits derived from wheat wild relatives and landraces. J Exp Bot 58: 177-186.

50. Iqbal, S., 2009. Physiology of Wheat (Triticum aestivum L.) Accessions and the Role of Phytohormones under water stress. Unpublished Ph.D. Thesis, Fac. of Biological Sci, Quaid-i-azam Univ, Islamabad 83-154.

51. Hammad SAR \& OAM Ali (2014). Physiological and biochemical studies on drought tolerance of wheat plants by application of amino acids and yeast extract. Ann Agric Sci 59: 133-145.

52. Filippou P, Antoniou C \& Fotopoulos V (2011). Effect of drought and rewatering on the cellular status and antioxidant response of Medicago truncatula plants. Plant Signal Behav 6: 270-277. 